\title{
A review of gas enhanced oil recovery schemes used in the North Sea
}

\author{
Afeez O. Gbadamosi ${ }^{1,2} \cdot$ Joseph Kiwalabye ${ }^{1} \cdot$ Radzuan Junin $^{1} \cdot$ Agi Augustine $^{1}$
}

Received: 28 June 2017 / Accepted: 24 February 2018 / Published online: 13 March 2018

(c) The Author(s) 2018

\begin{abstract}
The rate of replacement of produced oil and gas reserves by new discoveries is in a state of steady decline. Instead of searching for rare new oil fields, it is more economically justified to improve production from the existing and known fields. This is often achieved using enhanced oil recovery (EOR) technologies. The application of EOR in the North Sea dates to the mid-1970's with most of the fields being flooded with gas due to their light oils. Following a critical review of relevant published literature, the EOR methods in the past five decades are: water alternating gas (WAG), miscible gas injection (MGI), foam assisted water alternating gas (FAWAG), simultaneous water and gas (SWAG), and microbial enhanced oil recovery. The first part of this paper explores the advantages and limitations of the field implementation of gas EOR methods in North Sea oil fields. In the second part, new screening criteria of WAG, SWAG, MGI and FAWAG were developed by performing statistical analysis of the data from the past field experiences, especially in the North Sea. The screening criteria of the future methods are clearly documented in the literature and therefore not covered in this study. From the screening criteria, it has been identified that most North Sea fields qualify for WAG. This explains why WAG has been the most common scheme in the North Sea. FAWAG should also be implemented either after WAG or SWAG when the residual oil saturation is $<20 \%$.
\end{abstract}

Keywords Enhanced oil recovery $\cdot$ Water alternating gas $\cdot$ Recovery factor $\cdot$ Miscible gas injection $\cdot$ North Sea $\cdot$ Foam and water alternating gas

$\begin{array}{ll}\text { Abbreviations } \\ \text { WAG } & \text { Water alternating gas } \\ \text { SWAG } & \text { Simultaneous water and gas } \\ \text { FAWAG } & \text { Foam assisted water alternating gas } \\ \text { MGI } & \text { Miscible gas injection } \\ \text { MEOR } & \text { Microbial enhanced oil recovery } \\ \text { EOR } & \text { Enhanced oil recovery } \\ \text { WGR } & \text { Water gas ratio } \\ \text { RF } & \text { Recovery factor } \\ \text { AOS } & \text { Alpha olfenic sulphonate } \\ \text { CEOR } & \text { Chemical enhanced oil recovery } \\ \text { LS } & \text { Limestone } \\ \text { SS } & \text { Sandstone } \\ \text { MSL } & \text { Mean sea level }\end{array}$

Afeez O. Gbadamosi aogbadamosi2@live.utm.my

1 Department of Petroleum Engineering, Faculty of Chemical and Energy Engineering, Univesiti Teknologi Malaysia, 81310 Skudai, Johor Bahru, Malaysia

$\begin{array}{ll}\text { TVD } & \text { True vertical depth } \\ \text { Psi } & \text { Pound per square inch } \\ \text { cP } & \text { Centipoise } \\ \text { mD } & \text { Milli-darcy } \\ \text { HCPV } & \text { Hydrocarbon pore volume } \\ \text { MMP } & \text { Minimum miscibility pressure } \\ \mathrm{N}_{2} & \text { Nitrogen } \\ \mathrm{CO}_{2} & \text { Carbon dioxide } \\ \text { OOIP } & \text { Original oil in place } \\ \text { WF } & \text { Water flooding } \\ \text { BHP } & \text { Bottom hole pressure } \\ \text { Bpd } & \text { Barrels per day } \\ \text { FP } & \text { Formation pressure } \\ \text { SRB } & \text { Sulphur reducing bacteria } \\ \text { GOR } & \text { Gas oil ratio } \\ \text { PV } & \text { Pore volume } \\ \text { IFT } & \text { Interfacial tension } \\ \text { TDS } & \text { Total dissolved solids } \\ \text { SCF } & \text { Standard cubic feet } \\ \text { STB } & \text { Standard barrel } \\ \text { MPa } & \text { Mega-pascal } \\ & \end{array}$

2 Department of Chemical and Petroleum Engineering, College of Engineering, Afe Babalola University, PMB 5454, Ado Ekiti, Nigeria 


\section{Introduction}

About two-thirds of the original oil in place remain in the reservoir after primary and secondary production (Brown 2010; Bryant and Lockhart 2002; Shuker et al. 2012). To recover some of this oil, enhanced oil recovery (EOR) techniques are introduced in either the secondary or tertiary stage (Abbas et al. 2017; Agi et al. 2018a). These methods improve both the sweep and displacement efficiency with the intent of reducing the residual oil saturation (Bryant and Lockhart 2002; Yassin 1988; Speight 2009; Tunio et al. 2011). Depending on the type of injectant used, EOR is generally classified as thermal, gas, chemical, and microbial as shown in Fig. 1 (Ali and Thomas 1989; Amarnath 1999; Olajire 2014). Thermal methods such as steam flooding and in situ combustion involve the introduction of heat into the reservoir (Khalilinezhad et al. 2016). Chemical methods involve use of chemical solutions such as surfactants, polymers, and caustic solutions, and gas methods involve injection of slugs of either $\mathrm{CO}_{2}, \mathrm{~N}_{2}$, flue gas, or hydrocarbon to induce gas drive mechanisms within the reservoir (Shuker et al. 2012; Yassin 1988; Olajire 2014; Agi et al. 2018b). Meanwhile, microbial EOR involves the use of microorganisms which 'eat up' the oil to produce valuable chemicals that enhance oil recovery (Amarnath 1999; Olajire 2014; Bryant et al. 1989). These methods can increase the recovery factor to more than $50 \%$, hence extending the production life of a field (Tunio et al. 2011).

EOR methods increase ultimate oil production from the scarce oil fields, by reducing the residual oil saturation, and/ or improving the sweep efficiency (Hite and Bondor 2004;
Manrique et al. 2010). The efficiency of any EOR scheme greatly depends on the oil field properties, and therefore, accurate understanding of these properties is paramount (Yassin 1988; Hite and Bondor 2004; Teklu et al. 2012). The reservoir properties influence the mechanisms of oil recovery and ultimately the incremental oil (Breit 1992).

The selection of appropriate EOR scheme depends on the reservoir fluids and rock properties. Therefore, enhanced oil recovery schemes are reservoir specific (Ali and Thomas 1989; Satter et al. 2008; Przybylowicz and Rychlicki 2014). North Sea reservoirs are deep and have light and low viscosity oils (Watkins 2002). The sea temperatures average at $4{ }^{\circ} \mathrm{C}$ in the cold arctic region, which disqualifies the use of thermal energy in the North Sea. The large depth of the reservoirs only aggravates the challenge of using thermal methods due to associated large heat losses. Since oil is already light and low viscosity, polymer and thermal methods are impracticable, as the mobility ratio with sea water is already favourable. According to Awan et al. (2008) and Al Adasani and Bai (2011), five EOR schemes that have been applied in the North Sea are: WAG, FAWAG, SWAG, MEOR, and MGI (Awan et al. 2008; Al Adasani and Bai 2011). The use of surfactant polymer schemes and $\mathrm{CO}_{2}$ injection has been reported as future trends in the North Sea (Awan et al. 2008). The novel methods which include the use of electromagnetism and seismic stimulations are still under study and are outside the scope of this study.

There has been an observed change from MGI to WAG, FAWAG and SWAG schemes in the North Sea as shown in Table 1. However, the number of FAWAG and SWAG projects is still very few as the technologies are relatively new to the North Sea. It can be deduced that the current
Fig. 1 Classification of EOR technologies

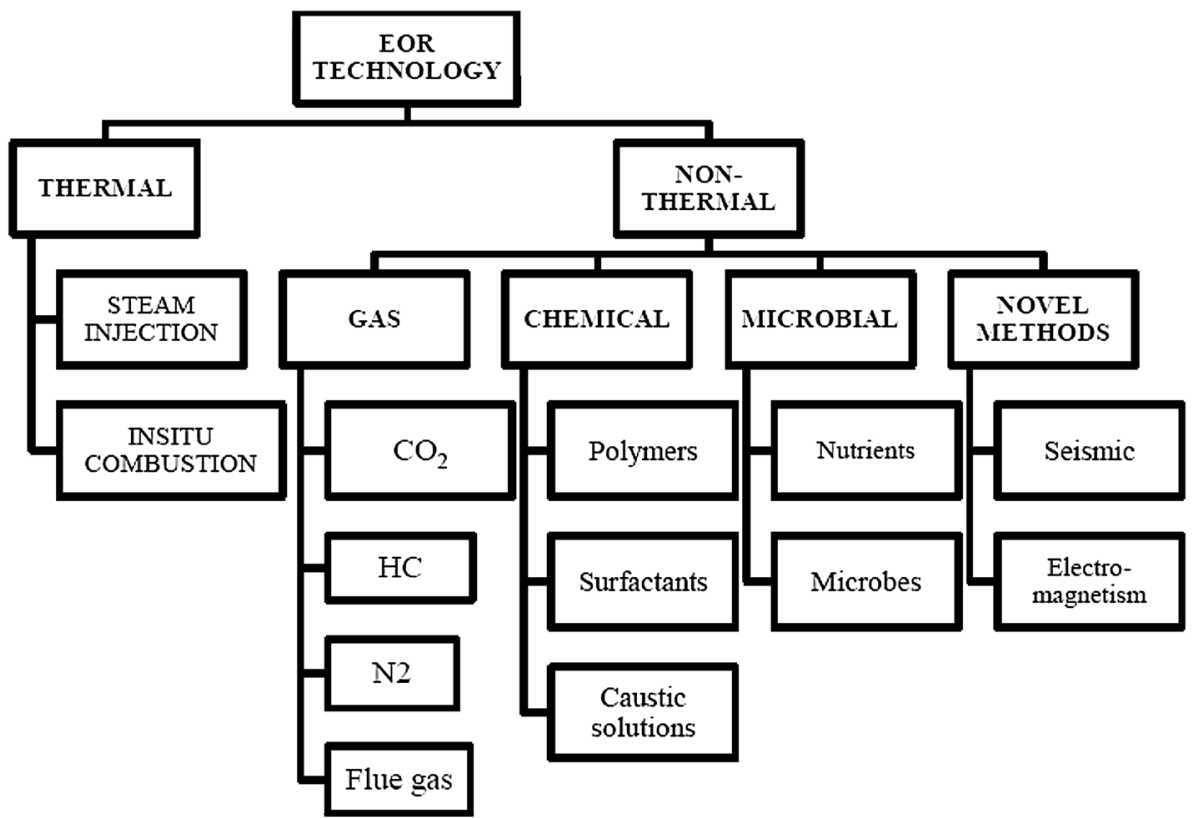


Table 1 Start date of the first projects of each of the EOR schemes in the North Sea. Reproduced with permission from Awan et al. (2008)

\begin{tabular}{llll}
\hline Project & Field name & Start date & $\begin{array}{l}\text { No. of } \\
\text { projects }\end{array}$ \\
\hline MGI & Ekofisk & 1975 & 6 \\
WAG & Thistle & 1980 & 9 \\
FAWAG & Snorre & 1997 & 2 \\
SWAG & Siri & 1999 & 1 \\
\hline
\end{tabular}

EOR methods are a combination of gas and water (multiphase scheme), for mainly mobility control of the gas and improved gas injection efficiency.

The first reported EOR schemes in the North Sea were initiated in the mid-1970s, and these were mainly MGI and WAG schemes. SWAG and FAWAG are much recent methods (Manrique et al. 2010; Awan et al. 2008). Taber et al. (1997a, b) published screening criteria of the EOR schemes. In their results, they produced a generalised criterion for all gas methods. Awan et al. (2008) performed a survey of the published EOR schemes in the North Sea. 95\% of the methods were all gas methods. The methods included WAG, SWAG, FAWAG, MGI, and MEOR (Awan et al. 2008). All these methods, apart from MEOR, are categorised as gas methods. Of the 652 projects reviewed by Al Adasani and Bai (2011), only 19 were from the North Sea, and of those 18 projects were gas methods. Their work included WAG and MGI schemes but did not include SWAG and FAWAG which have been reported as new schemes in the North Sea. Therefore, previous work has only provided generalised gas screening criteria and a more detailed screening of each of the methods would be needed for successful implementation. This study has used statistical evaluation methods as employed by Al Adasani and Bai (2011), to develop screening criteria for MGI, WAG, SWAG, and FAWAG for typical North Sea reservoirs. The developed criteria can be used as a guide for selection of the EOR gas method in the North Sea reservoirs. The criteria for screening the cited future methods such as the use of polymers, microorganisms, and $\mathrm{CO}_{2}$ are excluded, since they are well documented in the literature.

\section{North Sea EOR methods}

Majority of the North Sea fields have light oils, are heterogeneous, are in the cold arctic regions, are deep, are mostly offshore, and majority are of the Brent formation (Awan et al. 2008; Surguchev et al. 1992). This explains why gas or solvent methods have been the method of choice in the North Sea. The primary goal of gas EOR is to recover residual oil from water-swept reservoir area after secondary recovery with improved efficiency. It involves the use of gas (hydrocarbon, $\mathrm{CO}_{2}, \mathrm{~N}_{2}$, flue gas) which mixes with the oil in the reservoir through either multiple contact or single contact miscibility. Due to this distribution, a pseudo fluid with zero theoretical interfacial tension is formed within the reservoir (Asgarpour 1994).

Gas methods are usually employed in light low-viscous oil reservoirs, and the type of gas used depends on economics and availability (Healy et al. 1994; Alvarado and Manrique 2010). In the North Sea, only hydrocarbon gas has been used due to its availability compared to $\mathrm{CO}_{2}$ gas. Although $\mathrm{CO}_{2}$ flooding is said to recover more oil, it has been cited as a future method in the North Sea as the gas is not readily available. It has been observed that the main mechanisms of oil recovery by gas methods are miscible displacement, viscosity reduction, mobility modification, oil swelling and extraction, and gravity drainage (Marcel 1980).

During miscible gas flooding applications, reservoir pressure is built up above minimum miscibility pressure (MMP) when gas is injected to the reservoir. Consequently, gas mixes with the residual oil in porous media under consideration or evaporation mechanism. A pseudo fluid, which
Fig. 2 Gas miscible displacement

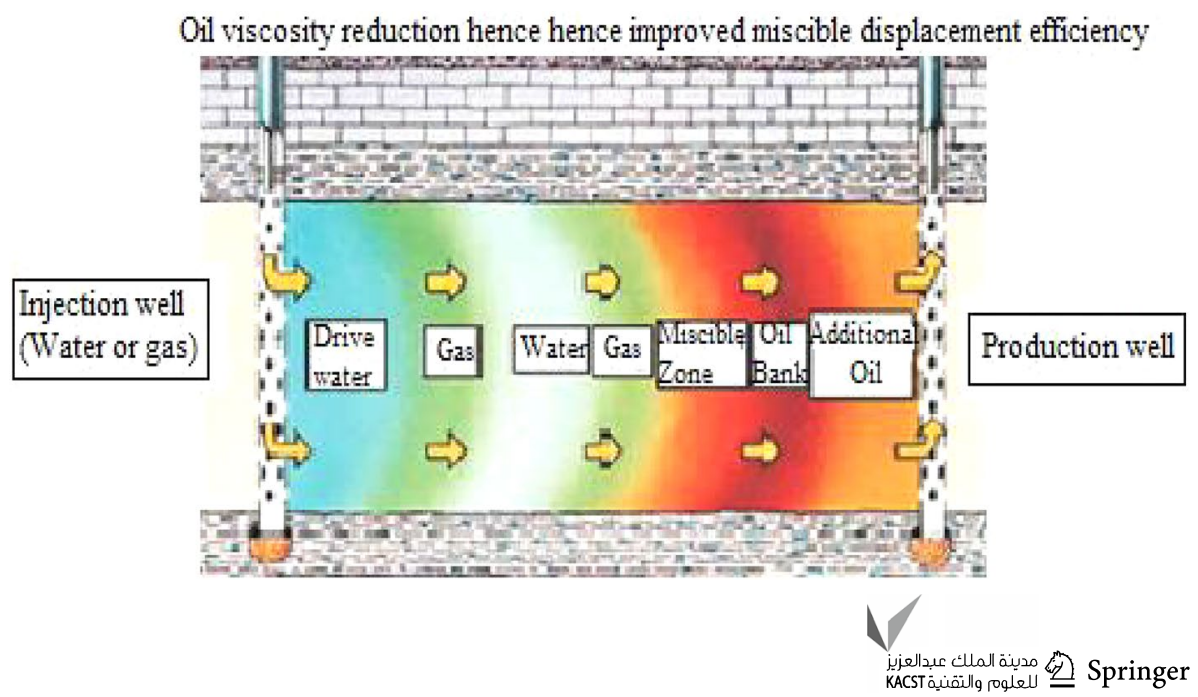


is more mobile than the oil, is formed within the reservoir, and eventually an oil bank accumulates at the miscible front (see Fig. 2). In most cases, water is injected alternately with the intent of reducing the gas mobility. A continued process entails a common EOR scheme referred to as water alternating gas (WAG) (Asgarpour 1994; Healy et al. 1994). When the gas and water are injected simultaneously, the process is referred to as (simultaneous water and gas injection) SWAG. If a surfactant is added to the water to induce foam to control the mobility of the displacing fluids, the process is referred to as foam assisted water and alternating gas (FAWAG). Sometimes, gas is injected as a single slug, in which case the scheme is referred to as miscible gas injection (MGI). Gas methods are the most common schemes in the North Sea. Though highly efficient, the short comings of the gas methods include (Syahputra et al. 2000; Koval 1963; Chang et al. 1994; Waggoner et al. 1992; Joekar-Niasar and Majid Hassanizadeh 2011):

- High reservoir pressure For maximum oil recovery, the reservoir pressure must be above the minimum miscibility pressure (MMP). If the pressure is below the MMP, then the process will be immiscible. Immiscible flooding does not recover as much oil as miscible flooding. Sometimes water is injected to increase the pressure prior to the miscible flood.

- Gravity override The injected gas tends to rise to the top of the formation due to gravity effects as seen in Fig. 3, and hence, a large section of the bottom oil is missed (Asgarpour 1994). Gravity override leads to low oil recoveries and limits gas methods to mainly thin formations.

- Reservoir Heterogeneities These are wide variations in porosities and permeability within the reservoir and are usually caused by stratification. Reservoir heterogeneities can affect oil recovery by gas injection as some of the displacing fluid may not be able to reach the low permeability formations (Healy et al. 1994).

- Hydrate formation Hydrates are crystalline structures of gas molecules trapped in lattice stabilised by water molecules. Since gas is co-injected with water during gas flooding, the risk of hydrate formation at the high reservoir pressures is high. Hydrate formation has been reported as a challenge at the Ekofisk field in the North Sea (Awan et al. 2008).

- Injectivity problems Owing to the low density of gas, the gas hydrostatic pressure at the bottom of the well is very small compared to that of any liquid. This implies reduced bottom hole pressures and its pressure differential with that of the formation, which ultimately affects the gas flow rate (Strom et al. 1973; Quale et al. 2000).

\section{Water alternating gas (WAG) method}

WAG injection is an EOR process that was developed to mitigate the technical and economic disadvantages of gas injection (Muggeridge et al. 2013). The first idea leading to WAG injection was to gain positive aspects of water flooding and gas injection (Panjalizadeh et al. 2015; Zahoor et al. 2011). WAG scheme has been the most commonly used technology in the North Sea. By 2005, of the 19 EOR projects reported, 9 were using WAG (Awan et al. 2008). It is a process whereby one gas slug is followed by a water slug (Christensen et al. 2001; Al-Ghanim et al. 2009). The main reason of initiating WAG in the North Sea was to improve the microscopic and macroscopic sweep efficiency (Surguchev et al. 1992; Sanchez 1999; Kulkarni and Rao 2005). Water provides a better mobility ratio as most of the North Sea oil is of low viscosity. Gas being miscible with the oil reduces the IFT which improves the displacement efficiency, and recovery of the top oil missed during water injection. Therefore, a combination of water and gas (WAG) leads to
Fig. 3 Factors affecting miscible recovery to improve quality. Reproduced with permission from Healy et al. (1994)

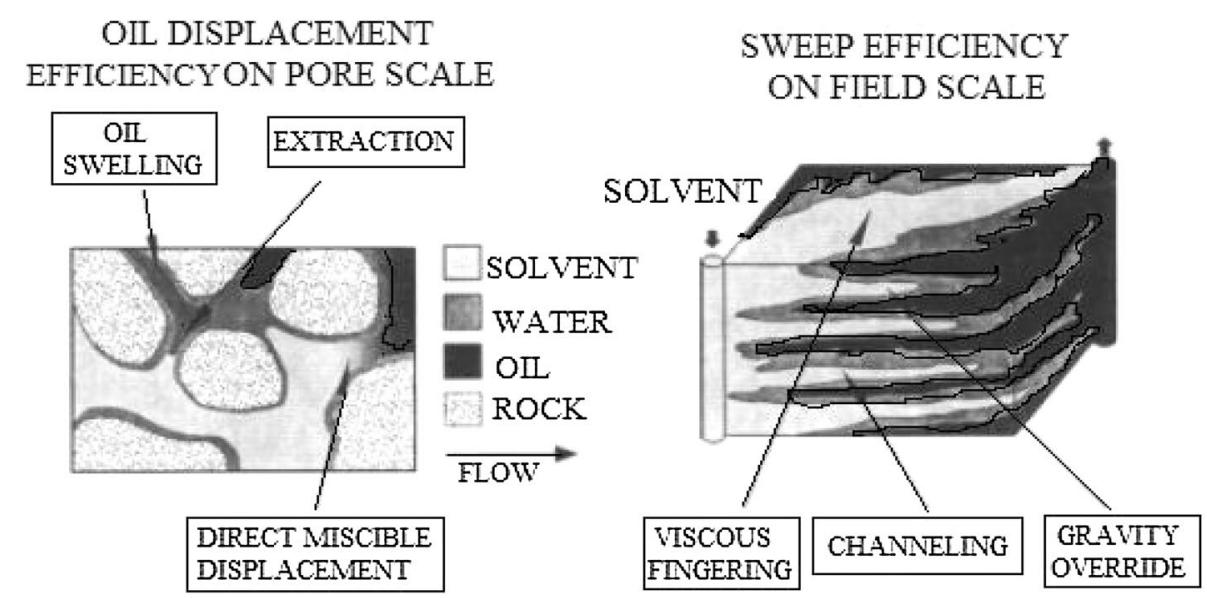


improved oil recovery (Sanchez 1999; Arogundade et al. 2013; Heidari et al. 2013; Green and Willhite 1998; Luo et al. 2013; Dashti and Sheikhzadeh 2013). WAG is usually applied in reservoirs with low dip, limited gas resources, and strong heterogeneity (Christensen et al. 2001). Hydrocarbon gas is the most commonly used gas in the North Sea because of its availability and low cost.

In the North Sea, WAG has been carried out at Snorre, south Brae, Magnus, Ula. Thistle, Gullfaks, Brage, Ekofisk, Statfjord, and Oseberg (Tables 2, 3), of which all are sandstone reservoirs with low-viscous oils $(<1.5 \mathrm{cp})$. The reservoir depths range from 2300 to $2900 \mathrm{~m}$, and injection method employed is down dip. The previous recovery method in all the fields was water flooding, and WAG was initiated to solve the poor displacement efficiency of water. However, the main challenges have been early gas break through due to reservoir heterogeneities and hydrate formation which even made Ekofisk unsuccessful (Awan et al. 2008). This has prompted a need to think about other schemes such as SWAG and FAWAG with expectation of better gas mobility control (Awan et al. 2008; Christensen et al. 2001).
Table 2 WAG schemes in the North Sea from 1975 to 2005. Reproduced with permission from Awan et al. (2008)

\begin{tabular}{lllllll}
\hline Field name & Prev. prod & $\begin{array}{l}\text { Prod. start- } \\
\text { up date }\end{array}$ & EOR start date & Inj. method & Injectant fluid & Result \\
\hline Snorre & WF & 1992 & 1994 & D-D & HC-r & Succ. \\
South Brae & WF & 1983 & 1994 & D-D & HC-r & Succ. \\
Magnus & WF & 1983 & 2002 & & HC-1 & Succ. \\
Ula & WF & & & & & \\
Thistle & WF & 1978 & 1980 & D-D & & Succ. \\
Gullfaks & WF & 1986 & 1991 & D-D & HC-1 & Succ. \\
Brage & WF & 1993 & 1994 & & HC-1 & Succ. \\
Ekofisk & WF & 1971 & 1996 & & HC-1 & Unsucc. \\
Statfjord & WF & 1979 & 1997 & D-D & HC-1 & Succ. \\
Oseberg & WF & 1999 & 1999 & D-D & HC-1 & Succ. \\
\hline
\end{tabular}

$D-D$ down dip injection, Succ. successful, HC-r enriched hydrocarbon gas, Unsucc. unsuccessful, HC-l lean hydrocarbon gas, $W F$ waterflooding

Table 3 Reservoir data for WAG field projects in the North Sea

\begin{tabular}{|c|c|c|c|c|c|c|c|c|c|}
\hline Field name & Oseberg & Magnus & Snorre & South Brae & Thistle & Gullfaks & Brage & Ekofisk & Statfjord \\
\hline Project type & Field app. & Field app. & Field app. & Field app. & Field app. & Field app. & Field app. & Field app. & Field app. \\
\hline Ref. & $\begin{array}{c}\text { Awan et al. } \\
(2008)\end{array}$ & $\begin{array}{l}\text { Awan et al. } \\
\text { (2008), } \\
\text { Zhang } \\
\text { et al. } \\
\text { (2013) }\end{array}$ & $\begin{array}{l}\text { Awan et al. } \\
(2008)\end{array}$ & $\begin{array}{l}\text { Awan et al. } \\
(2008)\end{array}$ & $\begin{array}{l}\text { Awan et al. } \\
(2008)\end{array}$ & $\begin{array}{l}\text { Awan et al. } \\
(2008)\end{array}$ & $\begin{array}{l}\text { Awan et al. } \\
(2008)\end{array}$ & $\begin{array}{c}\text { Awan et al. } \\
(2008)\end{array}$ & $\begin{array}{c}\text { Awan et al. } \\
(2008)\end{array}$ \\
\hline API & 38 & 39 & 35 & $33-37$ & 38 & $32-36$ & 36 & 36 & 41 \\
\hline Viscosity & - & - & 0.41 & 0.3 & 1.1 & 1.12 & 0.56 & 0.17 & 0.31 \\
\hline Porosity (\%) & 19 & - & & 11 & $18-23$ & 31 & 25 & $25-40$ & 28 \\
\hline $\begin{array}{l}\text { Formation } \\
\text { type }\end{array}$ & SS & SS & SS & SS & SS & SS & SS & LS & \\
\hline $\begin{array}{l}\text { Permeability } \\
\text { (md) }\end{array}$ & $1-1000$ & $10-1000$ & 200-2000 & 130 & $80-1220$ & $80-4500$ & $1-200$ & $0.1-100$ & 2300 \\
\hline $\begin{array}{l}\text { Pay zone } \\
\text { thickness } \\
\text { (m) }\end{array}$ & 35.7 & 200 & 90 & 09 & 168 & $250-300$ & 50 & 170 & 155 \\
\hline Depth (m) & 2770 & 2900 & 2300 & - & 2804 & 1740 & 2080 & 2900 & 2360 \\
\hline $\begin{array}{l}\text { Temperature } \\
\left({ }^{\circ} \mathrm{C}\right)\end{array}$ & 113 & - & - & - & - & 74 & 87.5 & 131 & 92 \\
\hline $\begin{array}{l}\text { Incremental } \\
\text { oil }(\%)\end{array}$ & 6 & 6 & - & 3 & & 10 & 5 & 3.3 & 7 \\
\hline $\begin{array}{l}\text { EOR start } \\
\text { year }\end{array}$ & 1999 & 2002 & 1994 & 1983 & 1980 & 1991 & 1994 & 1996 & 1997 \\
\hline
\end{tabular}


Surguchev et al. 1992, (Surguchev et al. 1992), considered a top Brent reservoir represented by Ness and Etive layers of Oseberg as a potential for WAG injection. The average depth of the reservoir was $3000 \mathrm{~m}$ MSL and its temperature, about $120^{\circ} \mathrm{C}$. It was identified that the important factors affecting WAG were: reservoir fluid properties, miscibility conditions, injection technique, and WAG parameters. The Ness layer was $22.4 \mathrm{~m}$ thick and the Etive layer $12.7 \mathrm{~m}$. NTU was 0.835 , horizontal permeability between 0.4 and $2064 \mathrm{mD}$ with an average of $466 \mathrm{mD}$. The vertical permeability was $0.87 \mathrm{mD}$, and the porosity was 16.36 and $17.22 \%$ for Ness and Etive layers, respectively. Increasing the mole fraction of methane in the injection gas increased the required MMP. $62.3 \%$ methane composition gave the least experimental MMP of 283.7 bar. Using a black oil simulator, it was shown that injectivity decreased with the number of WAG cycles due to the gas trapping effect. Maximum injectivity ratio of 0.128 was observed at the first cycle with a WGR of $2: 1$. The maximum oil recovery of WAG above constant injection was about $6 \%$ at $0.3 \mathrm{HCPV}$. In 1999, WAG was successfully implemented in the field as seen in Table 3.

Sanchez (1999) summarised the results of successful WAG projects. It was shown that WAG could improve recovery in Statfjord by 13\% above that of water flooding. The main factors anticipated to affect WAG injection process were: reservoir heterogeneity, rock wettability, fluid properties, miscibility conditions, trapped gas, injection technique, and WAG parameters, such as cycling frequency, slug size, WAG ratio, injection rate. Stratified reservoirs are good candidates for WAG. A $40 \%$ gas HCPV gave good recoveries between 9 and $15 \%$ at a WGR of 2:1. WAG is attractive in reservoirs with communicating layers, and SWAG is attractive in reservoirs with poor communication.

Christensen et al. (2001) reviewed about 60 WAG projects implemented from 1957 in Canada and the North Sea. A common trend of $5-10 \%$ incremental oil was observed for the successful injections. They pointed out that several new fields were being considered for WAG. Thirty-three projects were applied in sandstone reservoirs, 12 projects in dolomite, 5 mainly limestone, and 6 in carbonate. Only six projects were reported on offshore environment, and were all in the North Sea (Snorre, Brae South, Statfjord, Brage, Gullfaks and Ekofisk). The slug sizes of gas used were in the range of 0.1-3 PV. Improved recovery of miscible WAG was $9.7 \%$ and $3.3 \%$ more than immiscible WAG process. Thirty-three of the projects had oil viscosities $<4 \mathrm{cp}$. It can be concluded that North Sea is the offshore leader of worldwide WAG applications.

Erbas et al. (2014) reported that Magnus tertiary miscible gas injection which was started in 2002 through a WAG scheme, took the recovery factor close to $56 \%$ of the
OOIP. Magnus has a Magnus sandstone member (MSM) and a lower Kimmeridge Clay Formation (LKCF). The crest of the field is at a depth of $2900 \mathrm{~m}$ tvd. API is $39^{\circ}$ and GOR is around $700 \mathrm{scf} / \mathrm{stb}$. Bubble point pressure is 2508 psia, and the required MMP is 5000 psi. Miscible injection has been able to increase the recovery factor beyond $50 \%$.

\section{Miscible gas injection (MGI) method}

Miscible gas injection is an EOR process that improves microscopic displacement efficiency by reducing or removing the IFT between the oil and the displacing phase (the miscible gas) (Muggeridge et al. 2013). During MGI, a continuous slug of gas, either $\mathrm{CO}_{2}, \mathrm{~N}_{2}$, or $\mathrm{HC}$, is injected into the reservoir with the intent of reducing the residual oil saturation through creating miscible contact (Muggeridge et al. 2013; Zendehboudi et al. 2013; Farajzadeh et al. 2012; Teletzke et al. 2005). The main aim is to economically recover more hydrocarbon than water flooding (Farajzadeh et al. 2012; Lake 1989). Miscible gas injection falls under the same category of gas methods and therefore has the same mechanisms of oil recovery as other gas methods. MGI is well understood and easier to implement than the other gas methods (Batruny and Babadagli 2015).

In the North Sea, MGI has been carried out in Ekofisk, Beryl, Statfjord, Brent, Alwyn North, and Smorbukk South (see Table 4). Some studies show that miscible gas injection recovery can vary between 1.4 and $3.3 \%$ and can be initiated where it is not profitable to export gas. However, the method requires huge amounts of gas. Awan et al. (2008) stated that API above $23^{\circ}$, oil viscosity below $3 \mathrm{cp}$, and oil saturation above $30 \% \mathrm{PV}$, uniform permeability and a depth deeper than $1200 \mathrm{~m}$ to ensure miscibility, are ideal for MGI schemes. Hydrocarbon gas is the most commonly used gas in the North Sea because of its abundance. During MGI, oil is recovered by multiple miscible contact, IFT reduction, gravity drainage, oil swelling, and extraction mechanisms. Thin formations are recommended; however, high permeability streaks can be detrimental. Some of the limitations include gravity override, channelling, and poor mobility leading to early gas breakthrough.

Most of the EOR projects involving the use of $\mathrm{CO}_{2}$ reported to date have been carried out in the USA due to the readily available $\mathrm{CO}_{2}$ reservoirs (Moritis 2010). In the North Sea, $\mathrm{CO}_{2}$ flooding applications still require a comprehensive study to fully understand the $\mathrm{CO}_{2}$ behaviour in the North Sea field (Awan et al. 2008). Simulation studies have shown that efficiency of $\mathrm{CO}_{2}$ injection in the North Sea field is higher than that of water flooding applications. The main challenges expected to face this EOR technique are: transport of $\mathrm{CO}_{2}$, corrosion, hydrate formation, 
Table 4 Reservoir data for MGI projects in the North Sea

\begin{tabular}{|c|c|c|c|c|c|c|}
\hline \\
\hline \multicolumn{7}{|c|}{$\begin{array}{l}\text { MGI experience in the North Sea } \\
\text { Field name }\end{array}$} \\
\hline Project type & Field app. & Field app. & Field app. & Field app. & Field app. & Field app. \\
\hline Ref. & Awan et al. (2008) & Awan et al. (2008) & Awan et al. (2008) & Awan et al. (2008) & Awan et al. (2008) & Awan et al. (2008) \\
\hline API & 36 & 37 & 39 & 34 & 41 & 40 \\
\hline Viscosity (cp) & 0.17 & & 0.29 & 0.25 & 0.3 & 0.16 \\
\hline Porosity (\%) & $25-45$ & 17 & 21 & 25 & $15-20$ & 14 \\
\hline Formation type & LS & SS & SS & SS & SS & SS \\
\hline Permeability (md) & $0.1-100$ & 400 & 750 & 2000 & $5-2000$ & $1-600$ \\
\hline $\begin{array}{l}\text { Pay zone thickness } \\
\text { (m) }\end{array}$ & 60 & 124 & 63 & 27 & 95 & 117 \\
\hline MMP (bar) & & & $317-352$ & 407 & 375 & 400 \\
\hline Depth (m) & 3030 & 3200 & 2575 & 2744 & 3110 & 3900 \\
\hline Temperature $\left({ }^{\circ} \mathrm{C}\right)$ & 131 & & 99 & 103 & 113 & 140 \\
\hline Incremental oil (\%) & 3 & & & 1.4 & 3.3 & \\
\hline Remarks & Succ. & Succ. & Succ. & Succ. & Succ. & Succ. \\
\hline
\end{tabular}

environmental concerns due to early breakthrough. Amidst all these challenges, it is believed that $\mathrm{CO}_{2}$ injection will result in more oil recovery than $\mathrm{HC}$ injection as it readily mixes with the hydrocarbons at the pressure of most North Sea oil reservoirs. However, if executed successfully, the formations could provide massive storage for the greenhouse gas, especially when extracted from the atmosphere. Therefore, future trends of $\mathrm{CO}_{2}$ must focus on managing the challenges associated with the use of the technology to realise economic and environmental benefits. This has fuelled studies on carbon capture.

Akervoll and Bergmo (2010) performed simulation of $\mathrm{CO}_{2}$ EOR on 55 representative North Sea reservoirs viewed as potential candidates for the technology. It was postulated that the reservoir oil in many of the North Sea reservoirs would obtain miscibility owing to the reservoir conditions. The representative reservoir pressure was
317 bar, temperature was $101{ }^{\circ} \mathrm{C}$, depth was $2462 \mathrm{~m}$, and oil viscosity was $0.545 \mathrm{cp}$. All these properties were presumably very close to the field data from the Norwegian sector. The mean permeability in the sands also ranged between 100 and $1000 \mathrm{mD}$ and $0.1 \mathrm{mD}$ in the underlying mudstones. A conceptual maximum incremental oil recovery of $17.4 \%$ was realised in the North Sea shallow marine model. This is greater than the maximum of $10 \%$ that has been realised with hydrocarbon gas injection.

\section{Simultaneous water alternating gas (SWAG) method}

SWAG is an EOR process in which gas is mixed with water, and the mixture is then injected as two-phase mixture in the well to get better oil recovery (Tunio et al. 2011). When

Table 5 Reservoir data for SWAG field projects as well as some important Simulations

\begin{tabular}{|c|c|c|c|c|}
\hline Field name & Siri field & & Kapuruk & Gyda \\
\hline Project type & Field App. & Simulation & Pilot & Simulation \\
\hline Ref. & $\begin{array}{l}\text { Quale et al. (2000), Heidari et al. } \\
\text { (2013) and Jensen et al. (2012) }\end{array}$ & Zhang et al. (2013) & Jensen et al. (2012) & Zhang et al. (2013) \\
\hline API & - & 41 & 24 & $40-42$ \\
\hline Viscosity & & 0.86 & 2.5 & \\
\hline Porosity (\%) & $25-35$ & 25 & 23 & 16 \\
\hline Formation type & SS & & SS & \\
\hline Permeability (md) & $1-1000$ & $1-1000$ & $20-40$ & $1-800$ \\
\hline Pay zone thickness (m) & 25 & & 27 & \\
\hline MMP (bar) & & 348 & & 331 \\
\hline Depth (m) & 2070 & & 1890 & 4165 \\
\hline Temperature $\left({ }^{\circ} \mathrm{C}\right)$ & & 100 & 72 & 154 \\
\hline Remarks & Succ. & Succ. & Succ. & Succ. \\
\hline
\end{tabular}


water and gas injection are implemented simultaneously, the frontal stability increases resulting in better sweep efficiency (Zahoor et al. 2011). The challenges of early gas breakthrough during WAG and MGI have led to the initiation of SWAG schemes. In the North Sea, SWAG was first tried in the Seelington field in 1962 because they felt it would provide better oil recovery than WAG. A more recent application is in the Siri field (see Table 5), and an increased oil recovery of $6 \%$ compared to a water injection scheme was reported. In the Siri field, during WAG injection, rapid segregation of gas to the top of the formation affected the microscopic sweep of the bottom oil (Quale et al. 2000). This led to a change from WAG to SWAG in 1999. The SWAG process reduces the gas mobility and can improve injectivity, especially when the gas and water are co-injected using a single well (Al-Ghanim et al. 2009; Heidari et al. 2013; Algharaib et al. 2007). The SWAG mechanisms of oil recovery, which are miscibility, IFT reduction, gravity drainage, and mobility control, are like those of WAG (Heidari et al. 2013; Masalmeh et al. 2010; Tunio et al. 2011). SWAG can be implemented in two ways: (1) mixing the gas and water at the wellhead and then injecting it into the reservoir through highly deviated wells, (2) simultaneously injecting gas and water using different horizontal wells. The latter has been reported as that being used in the North Sea (Awan et al. 2008). The combined mobility of two phases is less than that of the injected single phase which implies better macroscopic sweep efficiency (Al-Ghanim et al. 2009; Ma et al. 1995). SWAG therefore delays gas breakthrough leading to reduced gas oil ratios (GOR). It has also been reported that in the Siri field, SWAG reduced the gas recompression requirements (Quale et al. 2000).

However, besides the envisaged advantages of SWAG, WAG is still the most common scheme in the North Sea. This is because injecting one phase is easier than injecting two phases at the same time (Awan et al. 2008). Injection of two phases may result in multiphase flow problems such as slug flow and hydrate formation, hence complicating injectivity (Ma et al. 1995). The phases could, however, be injected separately to improve injectivity. The gas is injected near the bottom of the formation and water near the top of the formation, using different horizontal injectors (Algharaib et al. 2007). This is a more recent approach and has been used in the North Sea Siri field. The problems associated with SWAG include: injectivity loss due to two-phase flow effects and hydrate formation as was experienced in the Siri field in the North Sea (Awan et al. 2008). In the North Sea, the future trend is more on WAG than SWAG due to associated equipment requirement of the latter. Most successful SWAG projects have been executed with a minimum of two horizontal wells. On the other hand, WAG is very flexible, as gas can be injected during summer when its demand is low.
Quale et al. (2000) identified that the isolated location of Siri field and the relatively small amounts of gas produced justified the re-injection of gas in the reservoir for improved oil recovery. The reservoir has a low relief structure, oil zone thickness of up to $25 \mathrm{~m}$, and GOR of $562 \mathrm{scf} / \mathrm{bbl}$. The oil zone is in the heimdal sandstone at a depth of $1020 \mathrm{~m}$ MSL. The sands have a high net-to-gross ratio, good porosity, and a good permeability. The SWAG injection was expected to give $6 \%$ incremental oil over water injection scheme. Fast segregation of the gas leading to poor vertical sweep efficiency and the gas trapping which affects injectivity ruled out the WAG scheme (Quale et al. 2000). Jamshidnezhad (2008) investigated the factors that affect miscible SWAG injection using a 3-D compositional finite-difference simulator, STARS. The simulation used properties of a typical North Sea oil with a viscosity of $0.86 \mathrm{cP}$ and API of $44^{\circ}$. Reservoir temperature was $100^{\circ} \mathrm{C}$, and the fluids were injected at 348 bar (MMP). The vertical permeability was 1-210 $\mathrm{mD}$ and the horizontal, 1-1000 $\mathrm{mD}$. Heterogeneity increased the non-uniformity of gas through the reservoir; however, segregation length was greater than the base case. The same factors that affected WAG, also affected SWAG.

\section{Foam and water alternating gas (FAWAG) method}

The largest full-scale demonstration of FAWAG was carried out in 1997 in the Snorre field in the North Sea (see Table 6) with the aim of improving the gas sweep efficiency. WAG was the first EOR scheme in the Snorre field in 1994, but was later changed to FAWAG scheme after 3 years (Spirov and Rudyk 2015). During WAG, there was an observed tendency of gas channelling to the high permeability zones and getting trapped. Another limitation of WAG is that oil recovery is only maximum during the first WAG cycle. In subsequent WAG cycles, due to the gas trapping, early gas breakthrough was observed at the Snorre field. Foaming of the injected gas was observed as a potential for the above-mentioned challenges of gas EOR method (Kovscek and Radke 1994; Du et al. 2008). It was shown that use of foam reduces the gas mobility factor, and sealing selected zones of the rock mass leading to a significant delay of gas breakthrough (Przybylowicz and Rychlicki 2014). Thus, the foam improves the sweep efficiency during gas injection while reducing the gas oil ratio (GOR) and maximising production rate in the producer well (Tunio et al. 2012; Liu et al. 2011). AOS surfactant was used to create the foam (Aarra et al. 2002). AOS surfactants are very good foaming agents and can significantly reduce gas mobility. They have been used successfully in the North Sea (Cubillos et al. 2012). However, high pressures above 400 bar may limit foam formation. Temperatures above $200{ }^{\circ} \mathrm{C}$ may also degrade the foam (Awan et al. 2008). Surfactants are chosen based on 
Table 6 Reservoir data for successful FAWAG projects

\begin{tabular}{|c|c|c|c|c|c|}
\hline Field name & Rock creek. WVA & Joffre Viking & North Ward-Estes & Oseberg/North Sea & Snorre \\
\hline Project type & Field app. & Field app. & Field app. & Field app. & Field app. \\
\hline Ref. & $\begin{array}{l}\text { Awan et al. (2008) and } \\
\text { Turta and Singhal } \\
\text { (1998) }\end{array}$ & Jensen et al. (2012) & Jensen et al. (2012) & Jensen et al. (2012) & Awan et al. (2008) \\
\hline API & 43 & $40-41$ & 37 & 38 & 34 \\
\hline Viscosity & 3.2 & 1 & 1.4 & 0.5 & $0.4-0.9$ \\
\hline Porosity (\%) & 21.7 & 13 & 18 & 16.4 & 24 \\
\hline Formation type & SS & SS & SS & SS & SS \\
\hline Permeability (md) & 21.5 & 500 & 15 & $2000-3000$ & $400-3500$ \\
\hline Pay zone thickness (m) & 7.6 & 3 & 18 & 66 & 12 \\
\hline MMP (bar) & & & & & 282 \\
\hline Depth (m) & 610 & 1500 & 800 & 2600 & 2300 \\
\hline Temperature $\left({ }^{\circ} \mathrm{C}\right)$ & & 56 & 28.33 & 100 & 90 \\
\hline Remarks & Succ. & Succ. & Succ. & & Succ. \\
\hline Start date & 1984 & 1990 & 1990 & 1994 & 1996 \\
\hline
\end{tabular}

their cost, adsorption, environment foaminess, and solubility (Cubillos et al. 2012). The use of surfactants in FAWAG enhances oil recovery in the following ways: (1) reduction in IFT thereby altering wettability (Li et al. 2012), (2) blockage of high permeable streaks, and (3) reduction of gas mobility (Simjoo et al. 2013; Al-mossawy et al. 2011). In FAWAG, a good surfactant must have the ability to form stable foam at the reservoir conditions. Foam stability depends on the oil saturation, reservoir and fluid properties, injection foam quality, and size of the chemical slug (Al-mossawy et al. 2011; Farzaneh and Sohrabi 2013).

Blaker (1999) investigated the use of foam for gas mobility control in the Snorre Field, one of the major oil fields in the North Sea, located $150 \mathrm{~km}$ offshore. The MMP was 282 bar. The foam was formed in the reservoir, when the gas gets in contact with water-surfactant solution in a process known as surfactant alternating gas (SAG). The aim was to reduce the GOR due to early breakthrough of the gas. In zones with direct communication, there was an observed tendency of early gas breakthrough due to the high gas mobility. It was urged that foam could be added to increase the viscosity of gas and therefore reduce its mobility and hence improve the gas sweep. Improving the sweep efficiency is pertinent to increasing oil recovery.

Aarra et al. (2002) demonstrated the breakthrough for FAWAG in the North Sea as applied in the Snorre field. The Snorre reservoir is a massive fluvial deposit within rotated fault blocks. The reservoir has high pressures ( $>300$ bar) and formation temperature of $90^{\circ} \mathrm{C}$. The project was a fullscale field demonstration of the use of foam to improve gas sweep. FAWAG was targeted for the upper Statfjord sandstone reservoir with a permeability in the range of $400-3500 \mathrm{mD}$ and an angle of dip $5^{\circ}-9^{\circ}$. The foam was intended to selectively plug the high permeability formation and hence improve the mobility ratio.

\section{Microbial enhanced oil recovery (MEOR) method}

Only one project has been reported to have used MEOR in the North Sea. However, limited data exist about this field application (Awan et al. 2008). To understand MEOR applications, it is important to analyse the studies that have been carried out on North Sea samples and field applications elsewhere. Since the chemicals produced during MEOR are the same as those used in CEOR, the two should be evaluated on the same basis. However, MEOR introduces reaction engineering into the perspective. Common criteria for MEOR are that the reaction time should be less than the residence time that the fluid spends in the bioreactor (Bryant and Lockhart 2002). This means that faster rates of reactions are required to produce the required concentration of chemicals. Similarly, slow rates of injection would give enough residence time for the microbes to grow and produce the desired chemicals. It is therefore ideal to shut in the wells and allow incubation of the microbes.

Thomas et al. (1993) performed core flooding experiments with Bacillus and sucrose-based nutrients on Berea sandstone cores for four different crude oils. The permeability of the cores ranged from 85 to $510 \mathrm{mD}$ and the API of the crude oils varied from $19.1^{\circ}$ to $38.1^{\circ}$. The bacteria used had a thermal tolerance of $50^{\circ} \mathrm{C}, \mathrm{PH}$ tolerance in the range 4.5-8.5. The incubation time of the microbes was 14 days at $37{ }^{\circ} \mathrm{C}$. The MEOR recovery was measured as a percentage of OOIP. The bacteria propagated through $110 \mathrm{mD}$ brine

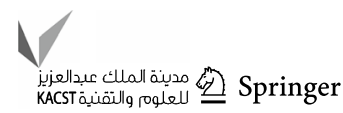


permeability of Berea sandstone. The stimulated incremental oil recovery varied between 1.4 and $13.8 \%$ of OOIP.

Gray et al. (2008) performed a critical review of MEOR methods and mechanisms for a representative North Sea reservoir sandstone. It was assumed that the bacteria, nutrients and products were uniformly distributed in the washed zones of the reservoir. The net pay thickness was $40 \mathrm{~m}$, porosity $24 \%$, and permeability ranged from 0 to $500 \mathrm{mD}$. The connate water saturation, $23 \%$, residual oil saturation at $15 \%$. The reservoir temperature was $99^{\circ} \mathrm{C}$, initial pressure was $38.6 \mathrm{MPa}$, bubble point pressure was $5.8 \mathrm{MPa}$, and oil viscosity was $1.1 \mathrm{cp}$. It was concluded that the most significant mechanism is blocking of high permeability zones, especially in fractured reservoirs. Other mechanisms such as formation of biosurfactants, alteration of wettability, solvent and gas production were identified as having poor potential towards MEOR.

Town et al. (2010) reported a successful MEOR process in a mature water flooded sandstone reservoir in Saskatchewan, Canada. The test well was shut in for several days to allow incubation of the microbes. The reservoir has three members with porosity ranging from $21.5 \%$ in the upper layer to $15.2 \%$ in the lower layers. Average permeability ranges from 53 to $567 \mathrm{mD}$. TDS is about $10 \mathrm{~g} / \mathrm{L}$ in the produced water, reservoir depth of $1200 \mathrm{~m}$ and temperature of $47^{\circ} \mathrm{C}$. Oil gravity is $22^{\circ}-24^{\circ} \mathrm{API}$. It was identified that there were very few documented applications of successful MEOR projects. There was an increase in oil production and oil recovery at a low implementation cost of about 6.00 USD per barrel of oil produced. MEOR schemes, if well implemented are inexpensive compared to other methods.

Zahner et al. (2012) reported the lessons learned from 100 MEOR treatments carried out in the USA and Canada from 2007 to the end of 2010. Based on laboratory data, it was estimated that MEOR could reach $10 \%$ of OOIP. Screening criteria were $80^{\circ} \mathrm{C}$, and water salinity was less than $10,000 \mathrm{ppm}$. Organic oil recovery was limited to reservoirs with $20^{\circ}$ API and greater. According to their survey, the reservoir permeability greater than $50 \mathrm{mD}$ is desirable for MEOR and with this condition the success rate was $90 \%$. They concluded that reservoir screening is critical to the success of MEOR. Another benefit of MEOR that was highlighted was the reservoir souring reducing effect as the multiplying microbes out-compete the SRB for food.

MEOR technology is immature in the North Sea and has only been carried out in the Norne field. The challenge is that no data have been published for this application. The MEOR screening criteria as specified by Lazar (1991) are: porosity of $\geq 20 \%$, permeability of $\geq 150 \mathrm{mD}$, reservoir temperature $\leq 70{ }^{\circ} \mathrm{C}$, salinity of $\leq 150 \mathrm{~g} / \mathrm{L}$ and oil viscosity of $5-50 \mathrm{cp}$. Use of microbes can promote selective plugging of high permeability zones in the North Sea and hence increase oil recovery in the un-swept zones. Limitations include corrosion in case of aerobic conditions, large quantities of nutrients required in case of anaerobic EOR, and poor understanding of the mechanisms involved (Awan et al. 2008). If well implemented and the mechanisms clearly understood, MEOR could be a success in the future of North Sea oil production.

\section{Screening criteria for North Sea EOR schemes}

The widely cited EOR screening guidance by Taber et al. (1997a, b) excludes some of the recent methods and projects (Al Adasani and Bai 2011). The methods that are available generalise the criteria for gas methods. In the North Sea, $95 \%$ of the EOR projects reported are gas methods; therefore, more detailed screening is required to distinguish between the various methods (WAG, SWAG, FAWAG, MGI). Since EOR projects are reservoir and fluid specific, most of the selection criteria are based on reservoir and fluid properties such as permeability, porosity, pay thickness, depth, initial and final oil saturations, operating pressure, API, viscosity, formation type (Al Adasani and Bai 2011; Taber et al. 1997a, b; Shokir et al. 2002). Al Adasani and Bai (2011) created a database of 652 EOR projects identifying each project, by country, EOR method used, and reservoir and fluid properties. Of the 652, only 18 projects were from the North Sea, and they were all grouped as gas methods. To develop a distinction, this study focuses on the selection criteria for the individual gas methods as they have been used in the North Sea. Al Adasani and Bai (2011); Taber et al. (1997b) updated EOR screening criteria to include Microbial EOR, $\mathrm{CO}_{2}$ injection, WAG and hot water flooding, but did not include SWAG and FAWAG which have also been reported as EOR schemes in the North Sea. This work, in addition to investigating the extent of EOR in the North Sea, through statistical analysis as used by Al Adasani and Bai (2011), has also developed selection criteria of the methods for future selection. Unfortunately, SWAG and FAWAG are new technologies and information about them is quite limited. For example, in the North Sea, only 3 projects have been reported. Therefore, some of the data used to develop their selection criteria have been acquired from recent laboratory work and simulations or field applications elsewhere, with properties identical to those of the North Sea fields. The criteria for the use of microbes, $\mathrm{CO}_{2}$, and polymers which have been reported as future EOR schemes in the North Sea are well documented in the literature and therefore out of the study scope. 


\section{Database building}

A database of all the North Sea EOR gas methods that have been reported in the literature is developed. The table fields include: API, viscosity, temperature, formation type, porosity, oil saturations, permeability, depth, field details, project start and end date. The gas methods were subcategorised as WAG, FAWAG, SWAG, and MGI. The database includes a total of 32 projects, of which 12 projects are FAWAG and SWAG from fields in Canada and the USA, with properties identical to those in the North Sea. These projects were considered because the North Sea field experience in FAWAG and SWAG is limited.

\section{Database analysis and screening criteria}

The first step was to construct the profile of the above gas methods only in the North Sea. The second step involved representing each EOR project by the field name and reservoir properties as shown in Tables 3, 4, 5 and 6, and finally a graphical representation of the distribution of each

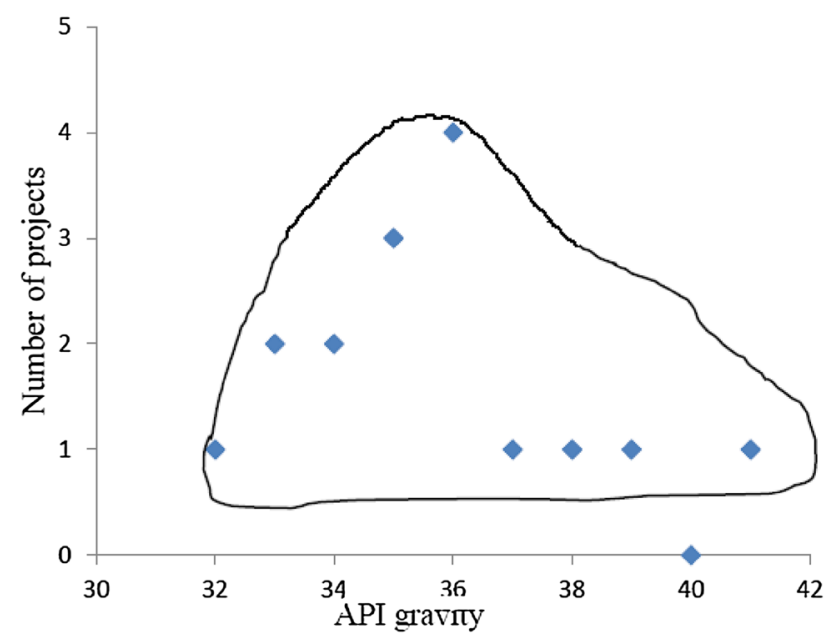

Fig. 4 Representation of API range for WAG projects reservoir property for a gas method to determine the range in which most projects were concentrated. For example, using API data from WAG projects in Table 3, the number of projects is plotted against the API as shown in Fig. 4. The field with API of 36 has the most number of projects. The minimum and maximum API values are 32 and 41, respectively, whereas the average value is 35.6. These values formed the API screening criterion for WAG project. The same procedure is repeated for each reservoir property to determine the overall WAG screening criteria in Table 3. Subsequent screening criteria of MGI, SWAG, and FAWAG were developed by a statistical analysis of their EOR projects in Tables 4, 5 and 6. The results of the screening criteria developed from the reported EOR survey of the North Sea are presented in Tables 7, 8, 9, and 10. It is worthy to note that light hydrocarbon gas is the commonly injected gas in the North Sea.

\section{Results and discussion}

WAG has been the most common scheme in the North Sea, whereas MGI projects formed the very first EOR schemes in the region. Multiphase injection schemes have replaced the single-phase schemes of either only water or gas. This has been attributed to early breakthrough of the single phases to the producing wells due to poor mobility ratios. Newer

Table 8 North Sea SWAG screening criteria

North Sea SWAG (hydrocarbon) selection criteria

\begin{tabular}{llll}
\hline Gravity (API) & $24-42(37.6)$ & Porosity $\%$ & $16-35(27.5)$ \\
Viscosity (cp) & $0.86-2.5(1.68)$ & Oil saturation (\%) & $>25$ \\
& & Formation type & SS \\
& & Permeability & $1-1000$ \\
& & $(\mathrm{md})$ & \\
& & Net thickness & Avg. 26 \\
& & Depth (m) & $1890-4165$ \\
& & & $(2708)$ \\
& & Temperature $\left({ }^{\circ} \mathrm{C}\right)$ & $72-154(109)$
\end{tabular}

Table 7 North Sea WAG screening criteria

\begin{tabular}{llll}
\hline North Sea WAG (hydrocarbon) selection criteria & \\
\hline Oil properties & & Reservoir properties \\
\hline Gravity (API) & $32-41(35.6)$ & Porosity $\%$ & $19-41(29)$ \\
Viscosity (cp) & $0.17-1.12(0.57)$ & Oil saturation (\%) & $>25$ \\
& & Formation type & SS or LS \\
& Permeability (md) & $0.1-4500$ \\
& Net Thickness (m) & $35.7-300(143)$ \\
& Depth (m) & $1740-2900(2481.75)$ \\
& Temperature $\left({ }^{\circ} \mathrm{C}\right)$ & $74-131(99.5)$ \\
\hline
\end{tabular}


Table 9 North Sea FAWAG screening criteria

North Sea FAWAG (hydrocarbon) selection criteria

\begin{tabular}{llll}
\hline Oil properties & \multicolumn{3}{l}{ Reservoir properties } \\
\hline Gravity (API) & $33-43(38)$ & Porosity \% & $13-24(18.62)$ \\
Viscosity (cp) & $0.4-3.2(0.58)$ & Oil saturation (\%) & $<20$ \\
& & Formation type & SS or LS \\
& & Permeability (md) & $2-4000$ \\
& & Net thickness (m) & $3-67(31.75)$ \\
& & Depth (m) & $610-4000(2967)$ \\
& & Temperature $\left({ }^{\circ} \mathrm{C}\right)$ & $59-100(87.3)$ \\
\hline
\end{tabular}

Table 10 North Sea MGI screening criteria

\begin{tabular}{llll}
\hline North Sea MGI (hydrocarbon) & selection criteria & \\
\hline Oil properties & \multicolumn{3}{l}{ Reservoir properties } \\
\hline Gravity (API) & $34-41(37.8)$ & Porosity $\%$ & $14-25(16.5)$ \\
Viscosity (cp) & $0.16-1.17(0.23)$ & Oil saturation & $>30$ \\
& $(\%)$ & \\
& Formation type & SS or LS \\
& Permeability & $0.1-2000$ \\
& $($ md) & \\
& Net thickness & $27-124(81)$ \\
& Depth (m) & $2575-3900$ \\
& & $(3093.2)$ \\
& & Temperature & $99-140(117.2)$ \\
& $\left({ }^{\circ} \mathrm{C}\right)$ &
\end{tabular}

multiphase schemes referred to as SWAG and FAWAG have also been applied in the North Sea environment. On this account, it is essential to compare the reservoir conditions of the most common schemes of WAG with the previous MGI schemes and with new EOR technologies in the North Sea. It is also important to draw a comparison between these new technologies to have an insight into their future of the North Sea EOR. The emerging technologies are FAWAG and SWAG.

\section{Comparison of WAG with MGI}

MGI is a single-phase scheme and therefore affected by high gas mobility. The schemes have been implemented in reservoirs with lower permeability contrast to limit channelling effects. To ensure miscibility, very large depths are required during MGI. From Table 10, it can be observed that the average depth is $3093 \mathrm{~m}$. MGI is also limited by the thickness of the formations. In very thick formations, gravity override effects may lead to the gas missing some of the bottom oil leading to poor sweep efficiencies. Therefore, the conditions required for MGI schemes are more limited as compared to
WAG. This justifies the trends of the shift from MGI towards WAG schemes.

\section{Comparison of WAG and SWAG}

WAG and SWAG are affected by the same factors, that is: hysteresis effects, gravity segregation, miscibility, gas breakthrough, water and gas slug size, injectivity, reservoir heterogeneities, and miscibility conditions. However, SWAG has been implemented in heavier gravity oils, because of the better mobility control during simultaneous injection with water. During injection of gas in alternation with water (WAG), the challenge of early gas breakthrough is not eliminated especially during the half cycle of gas injection. During WAG, gravity segregation plays a great role in oil recovery and therefore very good vertical communication of the reservoir is desirable. On the contrary, owing to the method of injection, SWAG may be implemented in reservoirs with poor vertical permeability, especially when the gas and water are injected using two separate horizontal wells. In most cases, SWAG is carried out in reservoirs with very thin pay zones, as seen in Table 4, to allow for formation of mixed flow zones of gas and water in the larger part of the reservoir. WAG may be carried out in thicker formations to allow for gas trapping.

\section{Comparison of WAG and FAWAG}

FAWAG may be implemented to solve the persistent challenge of high gas mobility during WAG. Foam reduces the gas mobility by plugging high permeability 'thief' zones, and hence delays gas breakthrough and reduces the GOR. Since FAWAG is limited by oil saturation, above $20 \%$, the scheme may be initiated after a WAG or SWAG schemes when the residual oil saturation has reduced to desired levels. High oil saturations encourage coalescence of the foam bubbles as the oil interacts with the foam and depletes its stability. High temperatures above $100^{\circ} \mathrm{C}$ may degrade the foam. In the North Sea, high salinity of sea injection waters, high adsorption rates of expensive chemicals, and high reservoir temperatures have limited field foam applications. The reservoir temperatures may be controlled by injecting cool sea water, and salinity may be reduced by mixing the sea water with fresh make-up water.

\section{Comparison of SWAG and FAWAG}

FAWAG may be carried out in reservoirs with high permeability contrast. The plugging effect of foam limits early gas breakthrough. High temperatures, high salinity, and high residual oil limit FAWAG. Because of these limitations, FAWAG may not be a good substitute for SWAG. If the 
economics allow, however, FAWAG may be initiated after SWAG.

\section{Conclusion and recommendations}

- The most practical EOR methods in the North Sea to date have been gas methods due to the light low-viscous oil. The gas schemes include WAG, SWAG, MGI, and FAWAG.

- Most of the North Sea oil reservoirs are WAG candidates. Hence, WAG is the most common scheme in the North Sea.

- SWAG may substitute WAG depending on the vertical conformity of the formation layers and the economics involved. Best SWAG projects have been implemented with two horizontal wells in the same vertical plane.

- FAWAG should be implemented after either SWAG or WAG in the North Sea. This is because it can reduce the residual oil below that of either WAG or SWAG.

- The use of polymers and chemicals in EOR is well understood worldwide, but no real field application in the North Sea has been reported. Future consideration of field application of polymers in the North Sea should focus on selective plugging of the high permeability streaks instead of providing mobility control as the North Sea oil is light and has low viscosity.

Open Access This article is distributed under the terms of the Creative Commons Attribution 4.0 International License (http://creativeco mmons.org/licenses/by/4.0/), which permits unrestricted use, distribution, and reproduction in any medium, provided you give appropriate credit to the original author(s) and the source, provide a link to the Creative Commons license, and indicate if changes were made.

\section{References}

Aarra MG, Skauge A, Martinsen HA (2002) FAWAG: a breakthrough for EOR in the North Sea. In: SPE annual technical conference and exhibition, 29 September-2 October, San Antonio, Texas. Society of Petroleum Engineers, pp 1-12

Abbas AH, Sulaiman WRW, Jaafar MZ, Aja AA (2017) Micelle formation of aerosol-OT surfactants in sea water salinity. Arab J Sci Eng. https://doi.org/10.1007/s13369-017-2593-0

Agi A, Junin R, Shirazi R, Afeez G, Yekeem N (2018a) Comparative study of ultrasound assisted water and surfactant flooding. J King Saud Univ Eng Sci. https://doi.org/10.1016/j.jksues.2018.01.002

Agi A, Junin R, Gbonhinbor J, Onyekonwu M (2018b) Natural polymer flow behaviour in porous media for enhanced oil recovery applications: a review. J Pet Explor Prod Technol. https://doi.org/10.1007/ s13202-018-0434-7

Akervoll I, Bergmo PES (2010) $\mathrm{CO}_{2}$ EOR from representative North Sea oil reservoirs. In: SPE international conference on $\mathrm{CO}_{2}$ capture, storage, and utilization, 10-12 November, New Orleans, Louisiana, USA. Society of Petroleum Engineers, pp 1-9
Al Adasani A, Bai B (2011) Analysis of EOR projects and updated screening criteria. J Petrol Sci Eng 79(1-2):10-24

Al-Ghanim W, Gharbi R, Algharaib MK (2009) Designing a simultaneous water alternating gas process for optimizing oil recovery. SPE-120375-MS, presented at EUROPEC/EAGE conference and exhibition, 8-11 June, Amsterdam, The Netherlands. Society of Petroleum Engineers, pp 1-21

Algharaib MK, Gharbi RB, Malallah A, Al-Ghanim W (2007) Parametric Investigations of a modified SWAG injection technique. In: SPE middle east oil and gas show and conference, 11-14 March, Manama, Bahrain. Society of Petroleum Engineers, pp 1-13

Ali SMF, Thomas S (1989) The promise and problems of enhanced oil recovery methods. In: Technical meeting/petroleum conference of the South Saskatchewan section, September 25-27, Regina. Petroleum Society of Canada, pp 1-11

Al-mossawy MI, Demiral B, Raja DMA (2011) Foam dynamics in porous media and its applications in enhanced oil recovery: review. Ijrras 7(June):351-359

Alvarado V, Manrique E (2010) Enhanced oil recovery: an update review. Energies 3(9):1529-1575

Amarnath A (1999) Enhanced oil recovery scoping study. An Electric Power Research Institute (EPRI) report, p 148. http://www.energ y.ca.gov/process/pubs/electrotech_opps_tr113836.pdf. Accessed 30 May 2017

Arogundade OA, Shahverdi H-R, Sohrabi M (2013) A study of three phase relative permeability and hysteresis in water alternating gas (WAG) injection. SPE-165218-MS, presented at SPE enhanced oil recovery conference, 2-4 July, Kuala Lumpur, Malaysia. Society of Petroleum Engineers, pp 1-16

Asgarpour S (1994) An overview of miscible flooding. J Can Pet Technol 33(2):13-15

Awan AR, Teigland R, Kleppe J (2008) A survey of North Sea enhanced-oil-recovery projects initiated during the years 1975 to 2005. SPE Reserv Eval Eng 11(3):497-512

Batruny P, Babadagli T (2015) Effect of waterflooding history on the efficiency of fully miscible tertiary solvent injection and optimal design of water-alternating-gas process. J Petrol Sci Eng 130:114-122

Blaker T et al (1999) Foam for gas mobility control in the Snorre field: the FAWAG Project. In: SPE annual technical conference and exhibition, 3-6 October, Houston, Texas. Society of Petroleum Engineers, pp 1-10

Breit VS (1992) Enhanced oil recovery: part 10. Reservoir engineering methods. In: Development geology reference manual, pp 527-539

Brown LR (2010) Microbial enhanced oil recovery (MEOR). Curr Opin Microbiol 13(3):316-320

Bryant SL, Lockhart TP (2002) Reservoir engineering analysis of microbial enhanced oil recovery. SPE Reserv Eval Eng 5(5):365-374

Bryant RS, Donaldson EC, Yen TF, Chilingarian GV (1989) Chapter 14-microbial enhanced oil recovery. In: Developments in petroleum science, pp 423-450

Chang Y-B, Lim MT, Pope GA, Sepehrnoori K (1994) $\mathrm{CO}_{2}$ flow patterns under multiphase flow: heterogeneous field-scale conditions. SPE Reserv Eng 9(3):208-216

Christensen JR, Stenby EH, Skauge A (2001) Review of WAG field experience. Soc Pet Eng J 4(2):97-106

Cubillos H, Montes J, Prieto C, Romero P (2012) Assessment of foam for GOR control to optimize miscible gas injection recovery. In: SPE improved oil recovery symposium, 14-18 April, Tulsa, Oklahoma, USA. Society of Petroleum Engineers, pp 1-11

Dashti HR, Sheikhzadeh A (2013) Improving oil production from fractured reservoirs using simultaneous water alternative gas (SWAG) injection scenario. World Appl Sci J 24(8):1000-1005

Du D-X, Beni AN, Farajzadeh R, Zitha PLJ (2008) Effect of water solubility on carbon dioxide foam flow in porous media:

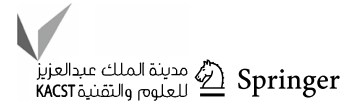


an X-ray computed tomography study. Ind Eng Chem Res 47(16):6298-6306

Erbas D et al (2014) Magnus WAG pattern optimization through data integration. In: SPE improved oil recovery symposium, 12-16 April, Tulsa, Oklahoma, USA. Society of Petroleum Engineers, pp 1-12

Farajzadeh R et al (2012) Foam-oil interaction in porous media: Implications for foam assisted enhanced oil recovery. Adv Coll Interface Sci 183-184:1-13

Farzaneh SA, Sohrabi M (2013) A review of the status of foam application in enhanced oil recovery. In: EAGE annual conference and exhibition incorporating SPE Europec, 10-13 June, London, UK. Society of Petroleum Engineers, pp 1-15

Gray M, Yeung A, Foght J, Yarranton HW (2008) Potential microbial enhanced oil recovery processes: a critical analysis. In: SPE annual technical conference and exhibition, 21-24 September, Denver, Colorado, USA. Society of Petroleum Engineers, pp 1-25

Green DW, Willhite GP (1998) Enhanced oil recovery. Society of petroleum engineers textbook series, p 545

Healy RN, Holstein ED, Batycky JP (1994) Status of miscible flooding technology. In: 14th world petroleum congress, 29 May-1 June, Stavanger, Norway. World Petroleum Congress, pp 407-416

Heidari P, Kharrat R, Alizadeh N, Ghazanfari MH (2013) A comparison of WAG and SWAG processes: laboratory and simulation studies. Energy Sources A Recovery Util Environ Eff 35(23):2225-2232

Hite JR, Bondor PL (2004) Planning EOR projects. SPE-92006-MS, presented at SPE international petroleum conference in Mexico, 7-9 November, Puebla Pue., Mexico. Society of Petroleum Engineers, pp 1-8

Jamshidnezhad M (2008) Oil recovery by miscible SWAG injection. In: SPE Russian oil and gas technical conference and exhibition, 28-30 October, Moscow, Russia. Society of Petroleum Engineers, pp 1-8

Jensen TB, Little LD, Melvin JD, Reinbold EW, Jamieson DP, Shi W (2012) Kuparuk river unit field - the first 30 years (SPE 160127PA). Presented at SPE annual technical and exhibition conference, San Antonio, TX, 8-10 October 2012, pp 4247-4259

Joekar-Niasar V, Majid Hassanizadeh S (2011) Effect of fluids properties on non-equilibrium capillarity effects: dynamic pore-network modeling. Int J Multiph Flow 37(2):198-214

Khalilinezhad SS et al (2016) Characterizing the role of clay and silica nanoparticles in enhanced heavy oil recovery during polymer flooding. Arab J Sci Eng 41(7):2731-2750

Koval EJ (1963) A method for predicting the performance of unstable miscible displacement in heterogeneous media. Soc Pet Eng J 3(2): 145-154

Kovscek AR, Radke CJ (1994) Fundamentals of foam transport in porous media. In: Foams: fundamentals and applications in the petroleum industry, pp 115-163

Kulkarni MM, Rao DN (2005) Experimental investigation of miscible and immiscible water-alternating-gas (WAG) process performance. J Pet Sci Eng 48(1-2):1-20

Lake LW (1989) Enhanced oil recovery. Society of petroleum engineers textbook series, p 550

Lazar I (1991) An overview of microbial enhanced oil recovery (MEOR) field trials, p 417. https://inis.iaea.org/search/searc h.aspx?orig_q=RN:26029035. Accessed 28 June 2017

Li RF, Hirasaki G, Miller CA, Masalmeh SK (2012) Wettability alteration and foam mobility control in a layered, 2D heterogeneous sandpack. Soc Pet Eng J 17(4):1207-1220

Liu M, Andrianov A, Rossen WR (2011) Sweep efficiency in $\mathrm{CO}_{2}$ foam simulations with oil. SPE-142999-MS, presented at SPE EUROPEC/EAGE annual conference and exhibition, 23-26 May, Vienna, Austria. Society of Petroleum Engineers, pp 1-18
Luo P, Zhang Y, Huang S (2013) A promising chemical-augmented WAG process for enhanced heavy oil recovery. Fuel 104:333-341

Ma TD, Rugen JA, Stoisits RF, Voungren GK (1995) Simultaneous water and gas injection pilot at the Kuparuk River Field, reservoir impact. In: SPE annual technical conference and exhibition, 22-25 October, Dallas, Texas. Society of Petroleum Engineers, pp 259-266

Manrique EJ et al (2010) EOR: current status and opportunities. In: SPE improved oil recovery symposium, 24-28 April, Tulsa, Oklahoma, USA. Society of Petroleum Engineers, pp 24-28

Marcel L (1980) Chapter 3-gas injection in an oil reservoir. In: Enhanced oil recovery, pp 83-95

Masalmeh SK, Hillgartner H, Al-Mjeni RA-M, Jing X (2010) Simultaneous injection of miscible gas and polymer (SIMGAP) to improve oil recovery and sweep efficiency from layered carbonate reservoirs. In: SPE EOR conference at oil and gas West Asia, 11-13 April, Muscat, Oman. Society of Petroleum Engineers, pp $1-15$

Moritis $\mathrm{G}$ (2010) $\mathrm{CO}_{2}$ miscible, steam dominate enhanced oil recovery processes. Oil Gas J 108(14):36-40

Muggeridge A et al (2013) Recovery rates, enhanced oil recovery and technological limits. Philos Trans R Soc A Math Phys Eng Sci 372(2006): $1-25$

Olajire AA (2014) Review of ASP EOR (alkaline surfactant polymer enhanced oil recovery) technology in the petroleum industry: prospects and challenges. Energy 77:963-982

Panjalizadeh H, Alizadeh A, Ghazanfari M, Alizadeh N (2015) Optimization of the WAG injection process. Pet Sci Technol 33(3):294-301

Przybylowicz J, Rychlicki S (2014) Enhanced oil recovery processes in sandstone reservoirs containing light oil in offshore fields. AGH Drill Oil Gas 31(1):99-116

Quale EA, Crapez B, Stensen JA, Berge LI (2000) SWAG injection on the Siri field - an optimized injection system for less cost. In: SPE European petroleum conference, 24-25 October, Paris, France. Society of Petroleum Engineers, pp 1-9

Sanchez NL (1999) Management of water alternating gas (WAG) injection projects. In: Latin American and Caribbean petroleum engineering conference, 21-23 April, Caracas, Venezuela. Society of Petroleum Engineers, pp 1-8

Satter A, Iqbal GM, Buchwalter JL (2008) Practical enhanced reservoir engineering: assisted with simulation software. PennWell Corporation, Tulsa

Shokir EME-M, Goda HM, Sayyouh MH, Fattah KA (2002) Selection and evaluation EOR method using artificial intelligence. In: Annual international conference and exhibition, 5-7 August, Abuja, Nigeria. Society of Petroleum Engineers, pp 1-7

Shuker MT, Buriro MA, Hamza MM (2012) Enhanced oil recovery: a future for Pakistan. In: SPE/PAPG annual technical conference, 3-5 December, Islamabad, Pakistan. Society of Petroleum Engineers, pp 1-15

Simjoo M et al (2013) Novel insight into foam mobility control. SPE Journal 18(3):416-427

Speight JG (2009) Chapter 5-exploration and general methods for oil recovery. In: Enhanced recovery methods for heavy oil and tar sands, pp 133-184

Spirov P, Rudyk S (2015) Testing of Snorre field foam assisted water alternating gas (FAWAG) performance in new foam screening model. Oil Gas Sci Technol Revue d'IFP Energies nouvelles 70(6): 1025-1033

Strom NA, Bray JA, Berndtsson NG (1973) Enhanced recovery trends in Alberta. J Can Pet Technol 12(3):35-43

Surguchev LM, Korbol R, Haugen S, Krakstad OS (1992) Screening of WAG injection strategies for heterogeneous reservoirs. In: European petroleum conference, 16-18 November, Cannes, France. Society of Petroleum Engineers, pp 1-12 
Syahputra AE, Tsau J-S, Grigg RB (2000) Laboratory evaluation of using lignosulfonate and surfactant mixture in $\mathrm{CO}_{2}$ flooding. In: SPE/DOE improved oil recovery symposium, 3-5 April, Tulsa, Oklahoma. Society of Petroleum Engineers, pp 1-9

Taber JJ, Martin FD, Seright RS (1997a) EOR screening criteria revisited-part 2: applications and impact of oil prices. Soc Pet Eng 12(3):199-205

Taber JJ, Martin FD, Seright RS (1997b) EOR screening criteria revisited-part 1: introduction to screening criteria and enhanced recovery field projects. Soc Pet Eng J 12(3):189-198

Teklu TW et al (2012) Geomechanics considerations in enhanced oil recovery. In: SPE Canadian unconventional resources conference, 30 October-1 November, Calgary, Alberta, Canada. Society of Petroleum Engineers, pp 1-12

Teletzke GF, Patel PD, Chen A (2005) Methodology for miscible gas injection EOR screening. In: SPE international improved oil recovery conference in Asia Pacific, 5-6 December, Kuala Lumpur, Malaysia. Society of Petroleum Engineers, pp 1-11

Thomas CP et al (1993) Surfactant-based EOR mediated by naturally occurring microorganisms. Soc Pet Eng J 8(4):285-291

Town K, Sheehy AJ, Govreau BR (2010) MEOR success in southern saskatchewan. Soc Pet Eng J 13(5):773-781

Tunio SQ, Tunio AH, Ghirano NA, El Adawy ZM (2011) Comparison of different enhanced oil recovery techniques for better oil productivity. Int J Appl Sci Technol 1(5):143-153

Tunio SQ, Chandio TA, Memon MK (2012) Comparative study of FAWAG and SWAG as an effective EOR technique for a Malaysian field. Res J Appl Sci Eng Technol 4(6):645-648

Turta AT, Singhal AK (1998) Field foam applications in enhanced oil recovery projects: screening and design aspects (SPE 48895).
Presented at SPE international oil and gas conference and exhibition, Beijing, 2-6 November, pp 577-591

Waggoner JR, Castillo JL, Lake LW (1992) Simulation of EOR processes in stochastically generated permeable media. Soc Pet Eng $7(2): 173-180$

Watkins GC (2002) Characteristics of North Sea oil reserve appreciation. Q Rev Econ Finance 42(2):335-372

Yassin AAM (1988) Enhanced oil recovery in Malaysia. In: Offshore South East Asia show, 2-5 February, Singapore. Society of Petroleum Engineers, pp 775-782

Zahner R, Tapper S, Marcotte B, Govreau BR (2012) Lessons learned from applications of a new organic-oil-recovery method that activates resident microbes. Soc Pet Eng J 15(6):688-694

Zahoor MK, Derahman MN, Yunan MH (2011) Wag process designan updated review. Braz J Pet Gas 5(2):109-121

Zendehboudi S et al (2013) A developed smart technique to predict minimum miscible pressure-EOR implications. Can J Chem Eng 91(7):1325-1337

Zhang P, Brodie J, Daae V, Erbas D, Duncan E (2013) BP North Sea miscible gas injection projects review (SPE 166597). Presented at SPE offshore Europe oil and gas conference, Aberdeen, 3-6 September, pp 1-11

Publisher's Note Publisher's Note Springer Nature remains neutral with regard to jurisdictional claims in published maps and institutional affiliations. 